\title{
Hematopoietic and Lymphatic System Part
}

National Cancer Institute

\section{Source}

National Cancer Institute. Hematopoietic and Lymphatic System Part. NCI Thesaurus. Code C41166.

Any component of the system of organs and tissues, including the bone marrow, spleen, tonsils, and lymph nodes, involved in the production of blood considered together with the interconnected system of spaces and vessels between body tissues and organs by which lymph circulates throug hout the body. 